\author{
Maciej Menes \\ Magister \\ Zakład Badań Ekonomicznych, \\ Instytut Transportu Samochodowego \\ maciej.menes@its.waw.pl
}

\title{
Development of individual motorism in Poland in 1990-2015
}

\begin{abstract}
The article describes the development of individual motorism in Poland in the years 1990-2015. Characteristics includes quantitative development and brand evolution of the car fleet. Presented are changes in volume of production, export, institutional and individual imports and vehicle registration and scrapping. It also shows how the vehicle fleet changed according to the type of fuel used and the engine displacement. In addition to the statistical image of the passenger car fleet, the article presents changes in the automobility of the Poles in the years 1990-2015.
\end{abstract}

Keywords: Individual Motorism; Road Transport; Passenger Cars

\section{Introduction}

Individual motorism, that nowadays is the possession and use of a passenger car, is an important component of every modern transport system. Poland entered the era of mass automotive industry, for historical and economic reasons, with many years of delay. In total, in the quarter-century 1950-1974, only about 300,000 people were produced in the country. passenger cars. The delay in the development of the Polish passenger car industry resulted from the conscious actions of the authorities [5]. At the root of the virtually anti-motoritarian policy of the state were ideological prerequisites. It was not until 1975 that the level of motorisation of the society reaching 32 cars / 1000 inhabitants approached the world average of the sixties of the last century [11].

In the same year, motorisation rates even in other CEE countries ranged from: 50 cars / 1000 inhabitants in Hungary, through 101 cars / 1000 inhabitants in Czechoslovakia up to 112 cars per 1000 inhabitants in the former GDR [9]. The scale of Poland's withdrawal from the development of individual motorization is illustrated by the fact that it has over $70 \%$ of land transport passenger transport in 15 countries of Western Europe as early as 1970 and 80\% share in 1980 [1], with a 10\% share in Poland in 1970 and 18\% participation in 1980 [9]. However, it was a breakthrough moment in which Poland joined the world's "automotive fever."

The liberated motoring aspirations of the society have not been stopped by the economic crisis of the end of PRL, nor by the perturbations of the first years of systemic transformation.

The volume of production, exports, institutional and individual import, registration and cassation, passenger cars in the years 1990-2015

In 1990, 5.26 million passenger cars were registered in the country, in 1995 there were 7.5 million cars, in 2000 almost 10 million, in 2005 - 12.3 million, in 2010 - 17.2 million and in 2015 20, 7 million cars (table 1). In the quarter-century, the number of registered passenger cars increased nearly four times. 
The motorization rate of the society increased in that time from 137 cars per 1000 inhabitants to 539 cars per 1000 inhabitants with the average characterizing EU countries - EFTA amounting to 564 passenger cars per 1000 inhabitants.

In the first decade of transformation, the development of the national passenger car park was largely based on the supply of cars from national automotive plants. In the years 1990-2003, about 6 million passenger cars were delivered to the market, including 4.5 million new cars and approx. 1.5 million used cars from the so-called individual import [14].

Tab.1. Characteristics of automotive development in Poland in 1990-2015, in thous. passenger cars

\begin{tabular}{|c|c|c|c|c|c|c|c|c|c|}
\hline \multirow{2}{*}{ 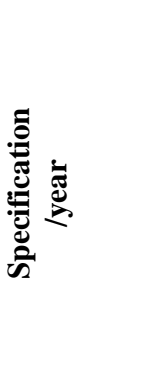 } & \multirow{2}{*}{ 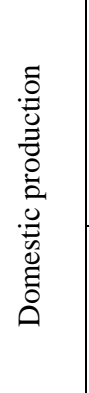 } & \multicolumn{2}{|c|}{ 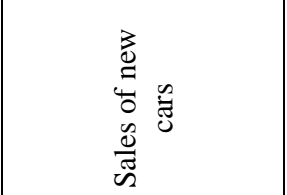 } & \multirow{2}{*}{ 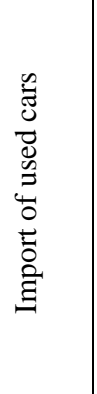 } & \multirow{2}{*}{ 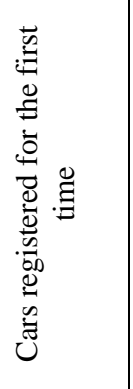 } & \multirow{2}{*}{ 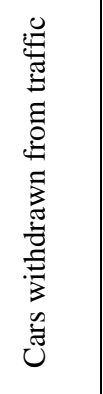 } & \multirow{2}{*}{ 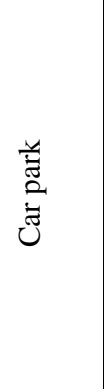 } & \multirow{2}{*}{ 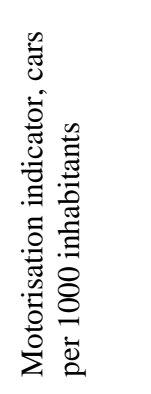 } & \multirow{2}{*}{ 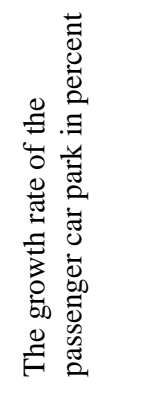 } \\
\hline & & altogether & \begin{tabular}{|c|} 
including \\
domestic \\
production
\end{tabular} & & & & & & \\
\hline 1990 & 266 & $\bullet$ & - & $\bullet$ & $\bullet$ & - & 5261 & 137 & $\bullet$ \\
\hline 1991 & 167 & 280 & 155 & 384 & 734 & $\bullet$ & 6112 & 160 & 16,1 \\
\hline 1992 & 218 & 223 & 147 & 212 & 471 & 78 & 26505 & 169 & 6,4 \\
\hline 1993 & 324 & 272 & 148 & 139 & 477 & 64 & 6770 & 176 & 4,0 \\
\hline 1994 & 328 & 297 & 178 & 144 & 486 & 91 & 7165 & 185 & 5,8 \\
\hline 1995 & 366 & 346 & 199 & 112 & 450 & 98 & 7517 & 195 & 4,9 \\
\hline 1996 & 441 & 475 & 214 & 152 & 627 & 90 & 8054 & 208 & 7,2 \\
\hline 1997 & 520 & 530 & 234 & 165 & 722 & 203 & 8533 & 221 & 6,0 \\
\hline 1998 & 592 & 515 & 247 & • & 558 & $\bullet$ & 8890 & 230 & 4,2 \\
\hline 1999 & 647 & 620 & 397 & $\bullet$ & 540 & $\bullet$ & 9500 & 245 & 6,8 \\
\hline 2000 & 532 & 480 & 475 & $\bullet$ & 519 & $\bullet$ & 9991 & 259 & 5,2 \\
\hline 2001 & 361 & 310 & 291 & 228 & 450 & $\bullet$ & 10503 & 272 & 5,1 \\
\hline 2002 & 298 & 300 & 140 & 179 & 421 & $\bullet$ & 11029 & 288 & 5,0 \\
\hline 2003 & 331 & 360 & 78 & 27 & 274 & $\bullet$ & 11248 & 294 & 2,0 \\
\hline 2004 & 522 & 231 & 54 & 828 & 833 & $\bullet$ & 11975 & 314 & 6,4 \\
\hline 2005 & 540 & 235 & $\bullet$ & 870 & 979 & $\bullet$ & 12339 & 323 & 3,5 \\
\hline 2006 & 609 & 238 & $\bullet$ & 817 & 924 & $\bullet$ & 13384 & 351 & 7,9 \\
\hline 2007 & 762 & 292 & • & 994 & 1129 & 182 & 14589 & 383 & 9,0 \\
\hline 2008 & 864 & 320 & 22 & 1103 & 1281 & 196 & 16079 & 422 & 10,2 \\
\hline 2009 & 819 & 320 & 17 & 693 & 864 & 204 & 16495 & 432 & 2,6 \\
\hline 2010 & 799 & 284 & $\bullet$ & 718 & 873 & 217 & 17240 & 451 & $\begin{array}{l}4,5 \\
\end{array}$ \\
\hline 2011 & 637 & 275 & $\bullet$ & 655 & 928 & 269 & 18125 & 472 & 5,1 \\
\hline 2012 & 550 & 273 & $\bullet$ & 657 & 909 & 384 & 18745 & 486 & 3,4 \\
\hline 2013 & 486 & 290 & $\bullet$ & 712 & 988 & 377 & 19389 & 504 & $\overline{3,4}$ \\
\hline 2014 & 472 & 328 & $\bullet$ & 749 & 1047 & 420 & 20004 & 520 & 3,2 \\
\hline 2015 & 535 & 296 & $\bullet$ & 792 & 1145 & $\bullet$ & 20723 & 539 & 3,6 \\
\hline Razem & 12721 & \begin{tabular}{|l|}
8390 \\
\end{tabular} & $\mathrm{X}$ & 11330 & $\mathrm{X}$ & $\mathrm{X}$ & & $\mathrm{x}$ & $\mathrm{X}$ \\
\hline
\end{tabular}


Source: own work based on:

- Statistical Yearbooks of the Central Statistical Office from 1992-2015

- GUS Transport Notebooks: Operating results from 1995-2015, and

- Menes E.: Dilemmas of the development of individual motorisation in Poland, ITS No. 87 Scientific Journal, Warsaw 1998

- Krzak J.: The effects of Poland's accession to the EU for the automotive industry, the Office of Studies and Expertise of the Chancellery of the Sejm, Report No. 224, Warsaw 2004

- Report of the Polish Association of Automotive Industry 2014, Warsaw 2015

Crisis phenomena did not bypass this sector (the number of passenger cars produced decreased from 351,000 units in 1980 to 167,000 units in 1991, but gradually as a result of further foreign investments (Fiat, Korean Daewoo, and General Motors), it began to grow to the level of 366 thousand cars in 1995 and 500-600 thousand cars in 1998-2000. In 2001-2003 production dropped again to the level of 290-360 thousand cars, to increase in 2005 to 540 thousand cars, in 2010 to 784 thousands of units (with 841,000 units in 2008.) In subsequent years, car production dropped to 740,000 cars (2011), 518,000 cars (2012), and 475,000 units in 2013-2014 (Figure 1) Fluctuations in the level of production of passenger cars are largely due to the fact that since Poland's accession to the EU almost $100 \%$ of the number of passenger cars produced in Poland, by both Fiat Auto Poland and GM Manufacturing Poland, is exported, so it will sell they depend on the situation on world markets. In 2012-2013, the level of exports oscillated around 550,000. passenger cars, and in the peak of 2009 exceeded 873 thousand. pieces, while institutional imports remained at the level of three hundred tens of thousands of cars [13].

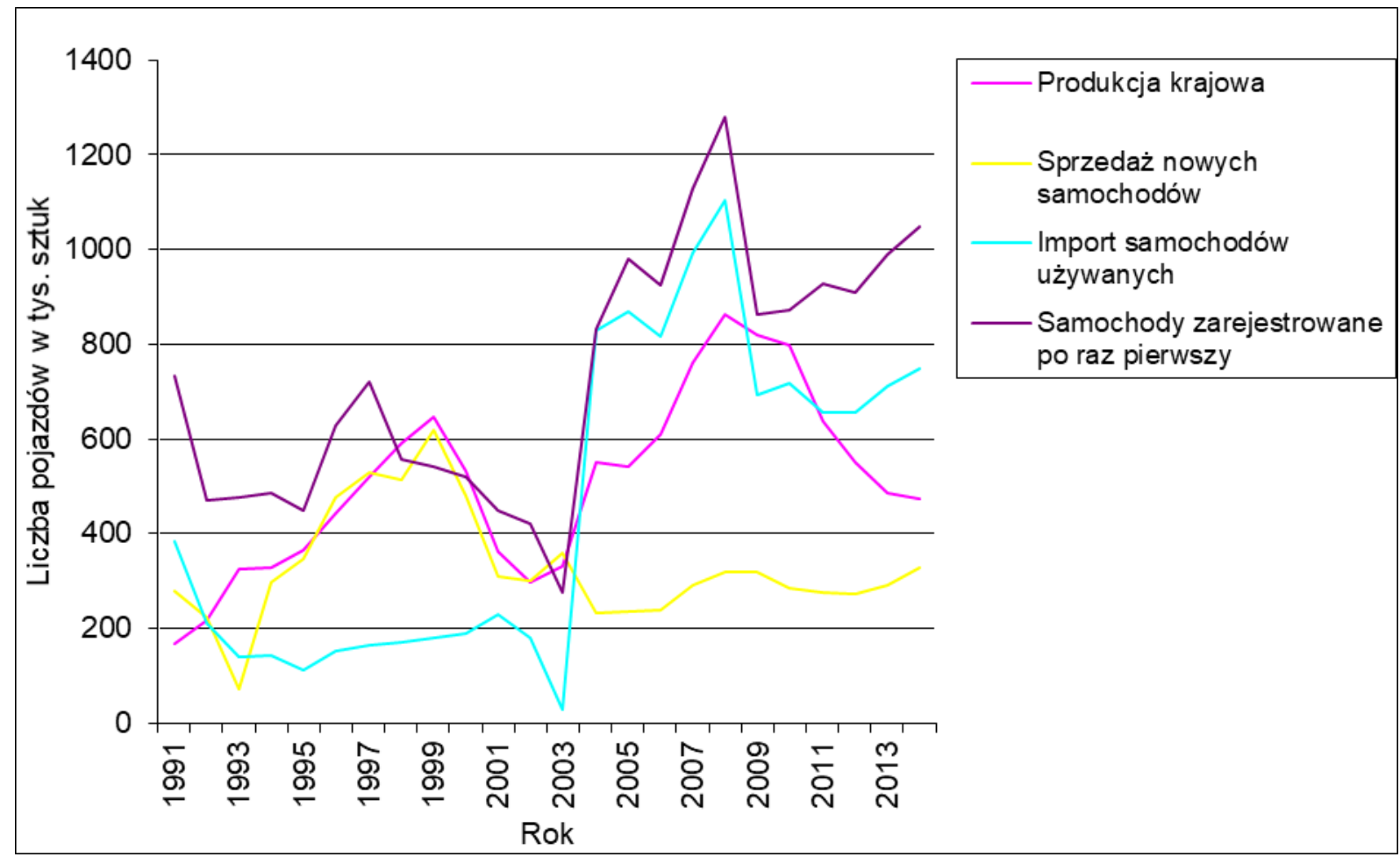

1. National production of passenger cars, sale of new cars, import of used cars, registration of passenger cars in the years 1991 - 2015, in thous. cars

Domestic sales of new passenger cars reached ca. 8.5 million vehicles in the quarter-century (production of 13 million vehicles), whereas in 1990-2000 about 60\% of new cars purchased came from the production of Polish automotive plants and $40 \%$ from institutional imports. The largest deliveries to the domestic market were carried out in 1996-2000 (about 1.4 million passenger cars, including only in 1999 over 600,000 cars). From 1999, deliveries of passenger cars produced in Poland to the domestic market began to gradually decline from 475 thousand 
cars. up to 53 thousand cars in 2003, and from this moment are only from several to several thousand vehicles per year. Practically all demand for new cars is covered by institutional imports of 300,000. vehicles annually. The sales index of 10 new cars / 1000 inhabitants is 34 times lower than analogous indicators in comparable countries [2].

The Poles began to acquire massively more or less used imported cars. In the first years of transformation, the import of used cars was hampered by relatively high customs rates, further strengthened by the introduction of a ban on the import of passenger cars over the age of 10 and not exceeding 10,000. pieces per year [14].

In 1999, the rules of individual importation of passenger cars were liberalized, which resulted in an increase of this import in 2000-2002 to the order of 200,000. cars a year. Another impediment to the import of passenger cars, but also the sale of new vehicles resulted in the introduction in 2003 of high rates of excise duty [14]. The liquidation of Poland's customs borders and environmental restrictions in May 2004 (the ban on the import of cars whose engines did not meet the Euro 2 standard) resulted in a sharp increase in the number of imported passenger cars, which has been practically up to now. During the first four months of 2004, preceding Polish accession to the EU, Poles imported 16 thousand. cars, and for the first 8 months of Poland's membership in the EU already more than 812 thousand. cars. A similar level of import of used passenger cars was maintained in subsequent years and amounted to: in 2005 - 870 thousand. cars, in 2006 - 816 thousand cars, in 2007- 990 thousand cars, in 2008 - 1100 thousand cars, in 2009 - 600 thousand cars, in $2010-720$ thousand cars, in 2011 - 710 thousand cars, in 2012 - 700 thousand cars, in 2013 - 712 thousand cars [8], in 2014 - 749 thousand. cars and in 2015792 thousand cars. Half of the imported, mainly used passenger cars, had already been over 10 years old when crossing the border.

In the entire analyzed period (1990-2015), imports of used passenger cars to Poland exceeded 11 million vehicles, of which $86 \%$ (9.5 million vehicles) were imported in 20042015, sales of new cars reached approx. 8.4 million vehicles and 5-6 million vehicles were withdrawn from registration (Table 6).

The low level of registered cassation of depleted passenger cars reaching, depending on the year, only $1-2 \%$ of the registered passenger car park is one of the essential factors, apart from the age structure of imported used cars, factors shaping the highly unfavorable age structure of the entire Polish fleet. According to various sources, from 20 to $25 \%$ of the number of passenger cars registered in Poland are vehicles existing only in registers, see e.g. 1.9 million Fiat 126 or 700 thousand Fiat 125, still in the register. According to Cepik, the number of registered passenger cars, whose data have not been updated in the last 5 years, reached in 20155476 thousand. pieces [12].

\section{Structural and quantitative changes of the Polish passenger car park in 1990-2015}

Poland entered the era of transformation with a park of passenger cars with about 5 million vehicles. In 1989, there were 4.85 million passenger cars registered in the country. Domestic vehicles dominated among them (about 4 million units and $75.5 \%$ of the park), of which about 2.2 million Fiat 126p and over one million Fiat 125. The second group in terms of participation in the park were passenger cars produced in European countries Central Eastern (over 700,000 units - 13.5\%).

A similar share was held by cars from Western European countries ( 0.5 million pieces - 10.4\%). The minimum share in the park was owned by Asian vehicles (less than 100,000 units $-1.5 \%$ ). It was a relatively young car park, cars up to 5 years accounted for $25 \%$ of the park, cars aged 6-10 accounted for 30\% of the park, and cars over 10 years accounted for $45 \%$ of the park [9]. The quantitative development and brand evolution of the Polish passenger car park is illustrated in the tab.2 
Tab. 2. Quantitative development and brand evolution of the Polish passenger car park in 1990-2015, in thous. vehicles.

\begin{tabular}{|c|c|c|c|c|c|c|}
\hline Samochody produkcji polskiej & 1990 & 1995 & 2000 & 2005 & 2011 & 2015 \\
\hline Daewoo & 0 & 0 & 394 & 471 & 489 & 414 \\
\hline Fiat $126 \mathrm{p}$ & 2185 & 2390 & 2533 & 2220 & 2015 & 1915 \\
\hline FSO 125 & 1011 & 929 & 827 & 703 & 675 & 667 \\
\hline Polonez & 437 & 708 & 887 & 736 & 637 & 586 \\
\hline Cinquecento/Seicento & 0 & 112 & 413 & 507 & 508 & 420 \\
\hline Syrena & 341 & 252 & 206 & 180 & 180 & 180 \\
\hline Samochody produkcji polskiej razem & 3974 & 4391 & 5358 & 4817 & 4504 & 4182 \\
\hline \multicolumn{7}{|l|}{ Samochody produkcji krajów RWPG } \\
\hline Dacia & 55 & 59 & 47 & 39 & 55 & 90 \\
\hline Skoda & 106 & 289 & 463 & 532 & 740 & 920 \\
\hline Trabant & 90 & 154 & 122 & 100 & 98 & 96 \\
\hline Wartburg & 141 & 173 & 144 & 108 & 102 & 100 \\
\hline WAZ & 142 & 196 & 182 & 160 & 142 & 137 \\
\hline Samochodu produkcji krajów RWPG razem & 712 & 1024 & 1107 & 1069 & 1262 & 1470 \\
\hline \multicolumn{7}{|l|}{ Samochody marek azjatyckich } \\
\hline Honda & 4 & 24 & 69 & 129 & 284 & 345 \\
\hline Hyundai & 5 & 20 & 45 & 60 & 140 & 232 \\
\hline Mazda & 11 & 44 & 60 & 92 & 225 & 315 \\
\hline Mitsubishi & 6 & 20 & 35 & 61 & 145 & 185 \\
\hline Nissan & 20 & 49 & 100 & 170 & 326 & 393 \\
\hline Suzuki & 2 & 6 & 23 & 53 & 132 & 184 \\
\hline Toyota & 25 & 69 & 120 & 249 & 547 & 762 \\
\hline Sam. marek azjatyckich razem & 75 & 244 & 464 & 830 & 1820 & 2438 \\
\hline \multicolumn{7}{|l|}{ Samochody produkcji zachodnioeuropejskiej } \\
\hline Audi & 40 & 110 & 162 & 283 & 665 & 903 \\
\hline BMW & 19 & 42 & 60 & 142 & 352 & 511 \\
\hline Citroen & 9 & 32 & 81 & 151 & 322 & 452 \\
\hline Fiat & 47 & 184 & 468 & 683 & 864 & 857 \\
\hline Ford & 84 & 225 & 414 & 780 & 1265 & 1384 \\
\hline Mercedes & 83 & 136 & 172 & 256 & 475 & 585 \\
\hline Opel & 70 & 219 & 562 & 1134 & 1882 & 2089 \\
\hline Peugeot & 25 & 73 & 142 & 270 & 502 & 643 \\
\hline Renault & 23 & 100 & 255 & 483 & 967 & 1151 \\
\hline Seat & 1 & 17 & 92 & 201 & 378 & 464 \\
\hline Volkswagen & 132 & 313 & 508 & 1046 & 2067 & 2400 \\
\hline Volvo & 10 & 26 & 33 & 60 & 168 & 234 \\
\hline Samochody produkcji zach.-europ. razem & 545 & 1483 & 2963 & 5516 & 9975 & 11770 \\
\hline Inne marki oraz samochody niezidentyfikowane & 116 & 376 & 99 & 107 & 564 & 861 \\
\hline Ogółem samochody osobowe & 5210 & 7518 & 9991 & 12339 & 18125 & 20723 \\
\hline
\end{tabular}

Source: own work based on:

1990-1995: Menes E. Dilemmas in the development of individual motorization in Poland, ITS No. 87 Scientific Notebook, Warsaw 1998

2000-2005: Balke I., Waśkiewicz J., Balke M .: Study of the structure of the car park in 2007 and analysis of changes in the structure of brands and the age of cars registered in Poland in 2005-2007, work ITS / 6803 / ZBE, Warsaw 2009, attachment No. 1, pp. 1-24

2011: Balke I., Waśkiewicz J., Balke M .: Study of the structure of a car park in 2011, by brands and age of selected vehicles, work ITS / 6215 / ZBE, Warsaw 2013

2015: Balke I., Balke M .: Study of the structure of the national park of selected types of vehicles in 2014 and 2015. Status of registration and estimation of the number of used vehicles, work ITS / 6501 / ZBE, Warsaw 2016 
Until 1995, the number of passenger cars registered in Poland increased to 7.5 million units (an increase of 44\%). Still the park of registered cars, in comparison with the situation in countries with developed motorization, was characterized by relatively small diversity. Although the share of Polish production cars decreased to slightly more than 58\% (4.4 million vehicles), the national production cars still dominated the park (Fiat $126 \mathrm{p}-31.6 \%$ with $41 \%$ in 1990 , Fiat $125-12.3 \%$ at $19 \%$ in 1990 , Polonez $-9,4 \%$ at $8,3 \%$ in 1990). From $10.5 \%$ to almost $20 \%$ the share in the registered park of passenger cars of West European production vehicles increased, among which Volkswagen dominated (4.1\% share in the park), Fords (3\% share in the park) and Ople (2.9\% share) in the park) [2].

The share in the registered park of passenger cars of Asian brands, including Toyota (around 70,000) and Nissan (about 50,000), also increased from $1.5 \%$ to over 3\%. At the similar level of $13.5 \%$ (712 thousand vehicles in 1995), the share of passenger cars from Central and Eastern Europe remained. They were dominated by: Łada - 142 thousand units and Wartburg - 141 thousand pieces.

According to estimated data, $43 \%$ of registered passenger cars were equipped with engines and capacities below $1000 \mathrm{~cm}, 53 \%$ in engines with a capacity from 1000 to $2000 \mathrm{~cm}$, and $4 \%$ in engines with a capacity above $2000 \mathrm{~cm}$. Most vehicles (about 85\%) were equipped with spark-ignition engines (engines supplied with ethylene), and only less than $15 \%$ of vehicles had self-ignition engines. In 1995, the first 52,000 registered in Poland. cars with engines adapted to LPG (Liquefied Petroleum Gas). The age structure of the registered passenger car park began to gradually deteriorate.

In 2000, the park of registered passenger cars in Poland approached 10 million units (an increase of $33 \%$ compared to 1995) and at the same time, its diversification increased. The continuing increase in the number of registered Polish production cars (to nearly 5.4 million vehicles, including 2.5 million Fiat 126p, 900,000 Polonez and 830 thousand Fiat 125) was accompanied by a further decline in the share of this group of vehicles in the national passenger car park (up to 53.6\%), with a simultaneous drop in the share of CEE production cars to $11 \%$ (1.1 million cars, including over 460 thousand Skoda), the share of Western European production cars increased to almost 30\% (around 3 million cars, of which Opel dominated - 562,000 units and Volkswagen 508,000 units). The share of passenger cars of Asian brands also increased (to less than 5\%), among which Toyota and Nissan exceeded the limit of 100,000. registered cars [2].

With the share of cars with spark-ignition engines (around 85\%) remaining at a similar level, the share of cars with LPG-adapted engines increased to 6\%. The share of cars with self-ignition engines of just $8 \%$ was one of the lowest in European countries.

The share of cars up to 5 years old remained similar to the $16 \%$ level existing in 1995, but the share of cars aged from 10 to 15 years (up to 18 years) decreased at the expense of the share of the car group aged over 15 years (35.3\%). 8\%).In 2005, the park of registered passenger cars reached nearly 12.5 million vehicles (an increase of approx. 25\%). The share of Polish production vehicles dropped in the registered passenger car park to $38.6 \%$ and their number decreased by over 0.5 million (to 4.8 million units). Among the Polish production Fiat $126 \mathrm{p}$ cars still dominated (2.2 million units - a decrease of 0.3 million units), Polonez (730 thousand units - a drop by 150 thousand) and Fiat 125 (700 thousand units - a drop by 100 thousand) [2].

The first position in terms of the share in the registered park of passenger cars was the group of Western European cars (5.5 million vehicles, which accounted for $44.2 \%$ of the entire park). At the top of the ranking, the Opel and Volkswagen brands were maintained, respectively 1.1 million and 1.05 million vehicles.

The share of Asian brand cars also increased to $6.7 \%$ of the registered passenger car park. Among the 830 thousand Asian car brands began to grow into the Toyota leader - 250 
thousand vehicles before Nissan 170 thousand vehicles. Despite the decline in both the share and the number of registered cars, the third position was retained by a group of cars produced in Central and Eastern Europe (1.07 million vehicles - 8.6\% share), but it owed only to Czech Skoda (over 0.5 million registered vehicles), whose expansion equalized the progressive process of the crumbling of cars of the remaining brands RWPG (Lada, Wartburg, Trabant). The evolution of the structure of the Polish passenger car park by production regions is illustrated in Table 3.

Tab. 3. Evolution of the structure of the Polish passenger car park by production regions in 1990-2015. in \%.

\begin{tabular}{|l|r|r|r|r|r|r|}
\hline Specification / year & $\mathbf{1 9 9 0}$ & $\mathbf{1 9 9 5}$ & $\mathbf{2 0 0 0}$ & $\mathbf{2 0 0 5}$ & $\mathbf{2 0 1 1}$ & $\mathbf{2 0 1 5}$ \\
\hline Polish cars & 69,5 & 58,4 & 53,6 & 38,6 & 24,8 & 20,2 \\
\hline $\begin{array}{l}\text { Cars produced in Central and Eastern } \\
\text { Europe }\end{array}$ & 15,7 & 13,6 & 11,0 & 8,6 & 7,0 & 7,1 \\
\hline Cars from West European production & 11,5 & 19,7 & 29,6 & 44,2 & 55,0 & 56,9 \\
\hline Asian brands cars & 1,5 & 3,2 & 4,6 & 6,7 & 10,0 & 11,8 \\
\hline Unidentified cars & 1,8 & 5,1 & 1,2 & 1,9 & 3,1 & 4,0 \\
\hline
\end{tabular}

Source: own list based on data from the table 2

Tab. 4. Passenger cars by type of fuel used and engine displacement in 1990 - 2015, in thous. units.

\begin{tabular}{|r|r|r|r|r|r|r|}
\hline year & $\mathbf{1 9 9 0}$ & $\mathbf{1 9 9 5}$ & $\mathbf{2 0 0 0}$ & $\mathbf{2 0 0 5}$ & $\mathbf{2 0 1 0}$ & $\mathbf{2 0 1 5}$ \\
\hline Total cars (1) incl: & 5210 & 7518 & 9991 & 12339 & 17240 & 20723 \\
\hline with motors up to $1399 \mathrm{~cm}^{3}$ & $\bullet$ & $3157(2)$ & $\bullet$ & 6846 & 7521 & 8292 \\
\hline with motors up to $1400-1999 \mathrm{~cm}^{3}$ & $\bullet$ & $3982(3)$ & $\bullet$ & 4930 & 8198 & 10805 \\
\hline with motors up to $2000 \mathrm{~cm}^{3}$ & $\bullet$ & 375 & $\bullet$ & 562 & 1521 & 1625 \\
\hline Cars with spark ignition engines (4) incl: & $\bullet$ & 6602 & 8443 & 9154 & 10516 & 11315 \\
\hline to $1399 \mathrm{~cm}^{3}$ & $\bullet$ & $\bullet$ & $\bullet$ & 5879 & 6581 & 6912 \\
\hline $1400-1999 \mathrm{~cm}^{3}$ & $\bullet$ & $\bullet$ & $\bullet$ & 3012 & 3583 & 3998 \\
\hline$>2000 \mathrm{~cm}^{3}$ & $\bullet$ & $\bullet$ & $\bullet$ & 244 & 352 & 405 \\
\hline Cars with compression ignition engines (3) including: & $\bullet$ & 723 & 793 & 1259 & 3871 & 6090 \\
\hline to $1399 \mathrm{~cm}^{3}$ & $\bullet$ & $\bullet$ & $\bullet$ & 56 & 165 & 277 \\
\hline $1400-1999 \mathrm{~cm}^{3}$ & $\bullet$ & $\bullet$ & $\bullet$ & 967 & 3038 & 4969 \\
\hline$>2000 \mathrm{~cm}^{3}$ & $\bullet$ & $\bullet$ & $\bullet$ & 236 & 667 & 844 \\
\hline Cars with engines adapted to LPG in total $(3) \mathrm{incl}^{3}$ & - & $52(5)$ & $600(6)$ & 1305 & 2478 & 2977 \\
\hline to $1399 \mathrm{~cm}^{3}$ & - & $\bullet$ & $\bullet$ & 463 & 775 & 864 \\
\hline $1400-1999 \mathrm{~cm}^{3}$ & - & $\bullet$ & $\bullet$ & 781 & 1532 & 1850 \\
\hline$>2000 \mathrm{~cm}^{3}$ & - & $\bullet$ & $\bullet$ & 61 & 170 & 263 \\
\hline
\end{tabular}

${ }^{1}$ The difference between the registration status and the sum of cars by fuel type results from the functioning of the group of cars with engines of unrecognized capacity.

${ }^{2}$ Estimation of the number of cars with engines with a capacity of up to $1000 \mathrm{~cm} 3$ and with engines with a capacity of 1001 $2000 \mathrm{~cm} 3$ for Menes E .: Dilemmas for the development of individual motorisation in Poland, ITS Scientific Notebook No. 87, Warsaw 1998, p.

${ }^{3}$ The difference between the total number of passenger cars in other fuel groups and their total by engine capacity class are vehicles with engines with a capacity of more than $2000 \mathrm{~cm}^{3}$.

${ }^{4}$ The number of cars with LPG engines in 1995 - 2000 according to estimates: www.infosamochody, Statistical Review of Global LPGas, reduce the number of cars with gasoline engines provided by the Central Statistical Office (GUS).

${ }^{5}$ Cars with engines with cylinder capacity up to $1000 \mathrm{~cm}^{3}$.

${ }^{6}$ Cars with engines with cylinder capacity up to $1000-2000 \mathrm{~cm}^{3}$.

Source: own work based on:

1995 - Transport - Operating results in 1996, GUS Warsaw, 1997, tabl. 7 (35), p.30

2000 - Transport - Operating results in 2000, Central Statistical Office in Warsaw 2001, tabl. 17 (43), pp.37

2005 - Transport - Operating results in 2005, CSO Warsaw 2006, tabl. 20 (46) s.124.

2010 - Transport - Operating results in 2010, Central Statistical Office in Warsaw 2011, tabl. 22 (53) pp.137

2013 - Transport - Operating results in 2013, Central Statistical Office in Warsaw 2014, tabl. 20 (52) s.144

2015 - Transport - Operating results in 2015, Central Statistical Office in Warsaw 2016, tabl. 15 (48) p.141 and table 20 (53) p.146-148 
The age structure of the registered passenger car park has clearly deteriorated. The share of the group of cars up to 5 years old decreased from $24 \%$ to almost $13 \%$, and the share of the group of cars over 10 years increased from $54 \%$ to $61 \%$.The share of cars with spark ignition engines also decreased (from $85 \%$ in 2000 to around 80\%), at the expense of the increase in the share of both cars with self-ignition engines (from $8 \%$ to 10\%), and cars with engines adapted to LPG (from 6 to $10 \%$ ).

In terms of engine cubic capacity, small-size cars up to $1399 \mathrm{~cm} 3$ dominated, which constituted over $55 \%$ of all registered passenger cars (6.8 million cars) with a $40 \%$ share of cars with engine capacity of $1400-2000 \mathrm{~cm}^{3}$ and $5 \%$ share of cars with engines $\mathrm{o}$ displacement above $2000 \mathrm{~cm}^{3}$. The above shares were different in different groups of cars according to the type of fuel used. Small cars dominated in the group of cars with sparkignition engines (65\%), with the absolute dominance of cars with larger displacement engines in the group of diesel-fueled cars $(95.5 \%)$ and in the group of cars with engines suited to LPG $(65 \%)$. The structure of the passenger car park registered in 1990-2015 in terms of engine capacity and fuel used is shown in the table. 5 .

Tab. 5. Structure of the passenger car park registered in 1990-2015 in terms of engine capacity and type of fuel used, in\%.

\begin{tabular}{|c|c|c|c|c|c|c|}
\hline $\begin{array}{ll}\text { specification } & \text { year }\end{array}$ & 1990 & 1995 & 2000 & 2005 & 2010 & 2015 \\
\hline Cars in total including engines: & 100,0 & 100,0 & 100,0 & 100,0 & 100,0 & 100,0 \\
\hline to $1399 \mathrm{~cm}^{3}$ & • & $42(1)$ & • & 55,5 & 43,7 & 40,0 \\
\hline $1400-1999 \mathrm{~cm}^{3}$ & $\bullet$ & $53(2)$ & $\bullet$ & 39,9 & 47,5 & 52,1 \\
\hline$>2000 \mathrm{~cm}^{3}$ & $\bullet$ & 5 & $\bullet$ & 4,6 & 8,8 & 7,9 \\
\hline \multicolumn{7}{|l|}{ With engines: } \\
\hline spark ignition & $\bullet$ & $\bullet$ & 85,0 & 74,2 & 61,0 & 54,6 \\
\hline compression ignition & $\bullet$ & $\bullet$ & 8,0 & 10,2 & 22,6 & 29,4 \\
\hline engines adapted to LPG & $\bullet$ & $\bullet$ & 7,0 & 10,6 & 14,4 & 14,4 \\
\hline
\end{tabular}

In 2010, the park of registered passenger cars in Poland increased to 17,240 million vehicles (an increase as compared to 2005 by as much as $39 \%$ ). Such a high dynamics of changes both in size and in the structure of the park was caused by the appearance, at the time of Poland's accession to the EU, of mass import of used cars. The available data for 2011 show that with the reduction of the Polish car park to 4.5 million vehicles, their share in the whole passenger car park decreased to around 24.8\%. The number of passenger cars registered in Poland in West European production approached 10 million units, which accounted for 55\% of the total park. Among these cars dominated: Volkswagen - 2.1 million units, Opel - 1.9 million units, Ford - less than 1.3 million units and Renault about 1 million units) [2].

The Asian brands were ranked third, both in terms of the number of cars (1.8 million units) and their share in the registered passenger car park (10\%). Among them was Toyota 0.55 million and Nissan over 300,000 pieces and Honda - less than 300,000 pieces. The share of brand cars from Central and Eastern European countries dropped to $7 \%$ of all registered passenger cars, of which nearly 1.3 million vehicles, nearly $60 \%$ were Skoda.

As a consequence of the growing import of used cars (which in 2008 exceeded 1.1 million vehicles), of which cars up to 4 years of age accounted for 5 to $13 \%$ depending on the year (with the average for the period 2004-2015 - 8\%) and cars over the age of 10 constituted 
from 41 to $72 \%$ (with the average for the period 2004-2015 - 52\%), the age structure of the passenger car park registered in Poland further deteriorated. The share of cars aged up to 5 years has decreased from $12.7 \%$ to $10.8 \%$ (including cars up to 2 years from $5.2 \%$ to $4.2 \%$ ), while the share of cars over 10 years has increased from $61 \%$ to over $72 \%$ (including cars over 31 years from $3.6 \%$ to $8.4 \%$ ).

Among the passenger cars registered in 2010, the first place was taken by vehicles with medium-sized engines (8.2 million units - 48\%), overtaking a group of vehicles with engine capacity up to $1399 \mathrm{~cm}^{3}$ (7.5 million units - 44\%). The share of cars with engines with a cylinder capacity above $2000 \mathrm{~cm}^{3}$ has also increased to over $8 \%$.

In terms of the type of drive used, the advantage of cars with spark ignition engines was maintained (10.5 million - 61\% share), but the share of cars with self-ignition engines increased significantly from $10.5 \%$ (1.3 million units) to $22,5 \%$ (3.9 million units). The share of cars with engines adapted to LPG increased from 10.5\% (1.3 million units) to $14.5 \%$ ( 2.5 million units). There was no change in the regularity, according to which cars with low-spark ignition engines were dominated by low and medium-sized cars (97\%), and in the group of cars with self-ignition engines medium and high-speed cars $(97 \%)$.

In the group of cars with engines adapted to LPG, nearly $70 \%$ were cars with medium and high-speed engines. The above changes and trends illustrate the table data 4. In 2015, there were 20.7 million passenger cars registered in the country. All previously observed structural trends have been maintained. The park's share of registered passenger cars of Western European brands was further increased to $57 \%$, the largest of which were Volkswagen (2.4 million vehicles), Opel (2.1 million vehicles), Ford (1.4 million vehicles) and Renault (over 1, 1 million vehicles).

Tab. 6. Used passenger cars imported to Poland from 5/4/2004 to 12/31/2015 including age, in thous. pieces and in $\%$.

\begin{tabular}{|c|c|c|c|c|c|c|c|c|}
\hline \multirow[t]{2}{*}{ Year } & \multicolumn{2}{|c|}{ Up to 4 years } & \multicolumn{2}{|c|}{$5-10$ years } & \multicolumn{2}{|c|}{ Up to 10 lat } & \multicolumn{2}{|c|}{ altogether } \\
\hline & number & share $(\%)$ & number & share $(\%)$ & number & share $(\%)$ & number & share $(\%)$ \\
\hline 2004 & 30 & 3,7 & 195 & 23,6 & 602 & 72,7 & 828 & 100,0 \\
\hline 2005 & 43 & 5,0 & 248 & 28,5 & 579 & 66,5 & 870 & 100,0 \\
\hline 2006 & 55 & 6,7 & 281 & 34,5 & 480 & 58,8 & 815 & 100,0 \\
\hline 2007 & 100 & 10,1 & 395 & 39,7 & 489 & 50,2 & 994 & 100,0 \\
\hline 2008 & 150 & 13,6 & 479 & 43,4 & 475 & 43,0 & 1103 & 100,0 \\
\hline 2009 & 82 & 11,8 & 324 & 46,7 & 287 & 41,5 & 693 & 100,0 \\
\hline 2010 & 80 & 11,1 & 330 & 45,9 & 308 & 43,0 & 718 & 100,0 \\
\hline 2011 & 64 & 9,8 & 285 & 43,5 & 306 & 46,7 & 655 & 100,0 \\
\hline 2012 & 53 & 8,1 & 300 & 45,6 & 304 & 46,3 & 657 & 100,0 \\
\hline 2013 & 55 & 7,7 & 312 & 43,9 & 344 & 48,3 & 712 & 100,0 \\
\hline 2014 & 58 & 7,7 & 311 & 41,5 & 380 & 50,8 & 749 & 100,0 \\
\hline 2015 & 51 & 6,5 & 300 & 37,9 & 440 & 55,6 & 792 & 100,0 \\
\hline Razem & 821 & 8,6 & 3760 & 39,2 & 5002 & 52,5 & 9577 & 100,0 \\
\hline
\end{tabular}

Source: own work based on:

2004 -2008: $\quad$ Balke I., Balke M: Branded structure of the park of passenger cars registered in Poland, the quarterly ITS Car Transport No. 1/2010 p.31

2006 - 2014: $\quad$ Report of the Polish Association of Automotive Industry 2014 based on data from the Ministry of

2015: Finance, p. 37

Report of the Polish Association of the Automotive Industry 2015 based on data from the Ministry of Finance, p. 38 
In the second position, domestic production vehicles remained, but with only a $20 \%$ share. Slight declines in the registration of these cars (a loss of 50,000 Polonez or 8,000 Fiats $125 \mathrm{p}$ ), and even the maintenance of registration at a similar level (see Syrena - 180,000) leads to the formulation of a virtual life for many of these cars. This also applies to the group of cars from Central and Eastern Europe. It maintained a 7\% share in the entire registered park, but only as a result of registration increase of Skoda cars, which in 2015 accounted for over $62 \%$ of registered vehicles of this group, while the number of other brands (except for increasing Dacia), despite their rather historic character (e.g. Moskwicz, Trabant, Wartburg) remained at a similar or even unchanged level (Fig. 2).

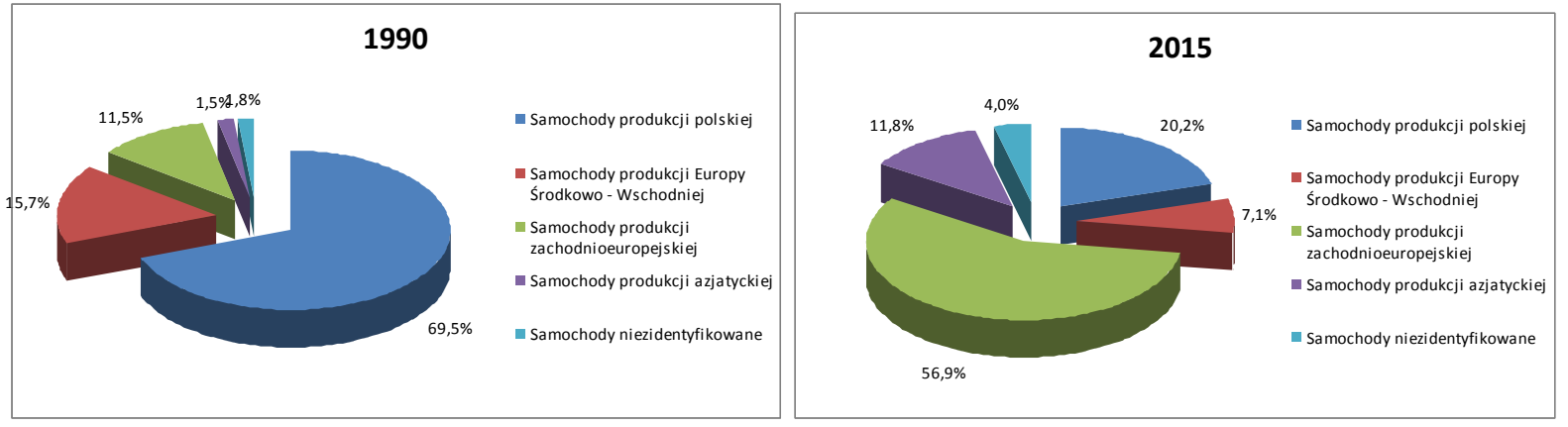

2. The evolution of the structure of the Polish passenger car park by production regions in the years 1990 - 2015, in\%

The position of Asian brands (almost 12\%) was further strengthened, among which the following year also dominated: Toyota (over 760,000 vehicles and Nissan nearly 400,000 vehicles).In terms of the types of drive used, the number of vehicles with self-ignition engines in the Polish passenger car park increased. The share of cars with self-ignition engines increased from $22.5 \%$ (3.9 million units) to $27 \%$ (5.3 million units). While maintaining a similar share of $14.5 \%$ (respectively 2.5 million units and 2.8 million units) of vehicles with engines adapted to LPG, the share of cars with spark ignition engines dropped from $61 \%$ (10.5 million units) to $56 \%$ (10.9 million items). The dominance of low and medium-sized cars in the group of vehicles with spark-ignition engines (97\%) and the dominance of cars with medium and high-speed engines in the group of cars with self-ignition engines did not change (96\%) [2].

The share of vehicles aged up to 5 in the park registered in Poland in 1991-2015 of passenger cars decreased from $42 \%$ in 1991 by $24 \%$ in 2000 to $9.3 \%$ in 2015 . At the same time, the share of cars in this park over the age of 15 years increased from $5.4 \%$ in 1991 by $35 \%$ in 2000 to around $55 \%$ in 2015.At the end of the nineties of the last century, the share of cars over 10 years increased to nearly $60 \%$ (with nearly $35 \%$ of registered passenger cars already over 15 years old), while the share of passenger cars up to 5 years old fell to $18.5 \%$ [9].

The largest increases in the share of vehicles in the park registered in Poland in 19902015 of passenger cars were recorded by Volkswagen from 2.5 to $11.6 \%$ (from 132 thousand to 2.40 million cars), Opel from $1.3 \%$ to $10.2 \%$ (from 70,000 to 2.1 million cars), Ford from $1.6 \%$ to $6.8 \%$ (from 84 thousand to 1.38 million cars) and Renault from $0.4 \%$ to $5.5 \%$ (from 23 thousand to 1.1 million cars). The largest decreases in the share of vehicles in the park registered in Poland in 1990-2015 of passenger cars concerned Polish cars: Fiat 126p from $41.5 \%$ to $9.2 \%$ (from 2.5 million in 2000 to 1.91 million in 2015 ), Fiat 125 p from $19.2 \%$ to $3.2 \%$ (from 1.0 million to 667 thousand cars), Polonez from $8.3 \%$ to $2.8 \%$ (from 887 thousand in 2000 to 586 thousand cars), (fig.3). 

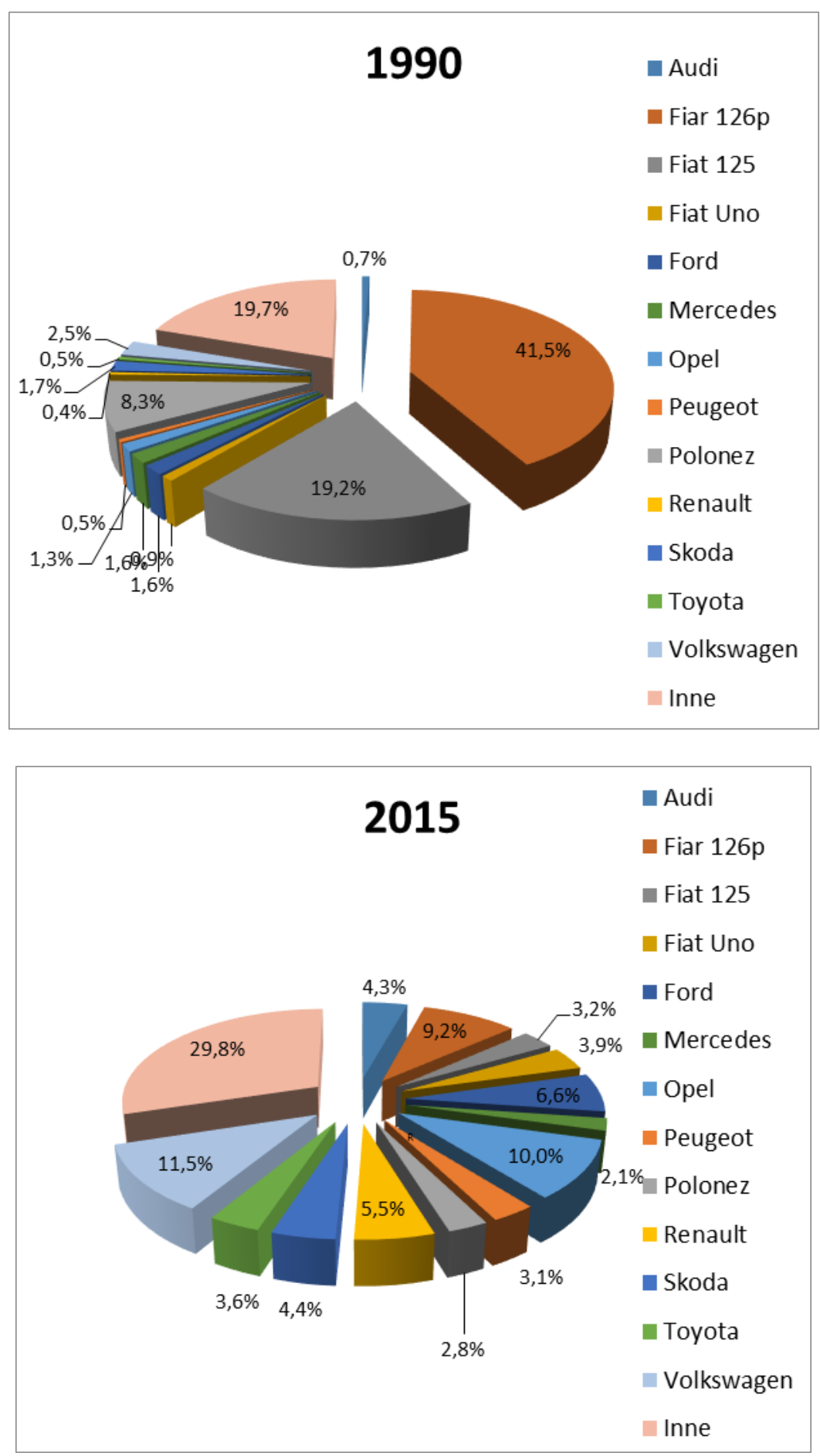

3. Share in the park of passenger cars registered in Poland of 13 most popular car brands in $1990-2015$, in $\%$

The unique growth dynamics of the park of registered passenger cars were accompanied by trends accompanying the development of motorisation in most countries consisting of a gradual increase in the share of vehicles equipped with engines with larger displacement volumes, a dynamic increase in the number of vehicles with self-ignition engines (at least until the scandal related to counterfeiting results of emission tests of cars with compression ignition engines in 2015). The phenomenon that distinguishes the development trends of the Polish automotive industry is the constant deterioration of the already unfavorable age structure of the owned passenger car park. 
This is a consequence of, on the one hand, still limited financial capabilities of Poles, with their simultaneously developed automotive aspirations, on the other hand, the lack of fiscal policy aimed at actively shaping the size and structure of imported used cars.In 20042015, Poles imported close to 9.5 million used passenger cars (the most, 1.1 million units in 2008 and the least in 2011/2012, 655,000 units). In this import cars dominated over 10 years $(52.5 \%)$, with the largest share in imported cars characterized by this group of vehicles in the first years of Poland's accession to the EU - in 2004 about 73\%, in 2005 65.6\%, in order to decrease in the following years $41.5 \%$ in 2009. From that moment, the share of cars over 10 years imported to Poland began to increase again to over 55\% in 2015.

In the park of registered passenger cars, there is a steady increase in the share of vehicles with large displacement engines exceeding $2000 \mathrm{~cm} 3$ from $5 \%$ in 1995 to over $8 \%$ in 2015 and $40 \%$ in 2005 to $52 \%$ in 2015 cars with engine capacity 1400- $1999 \mathrm{~cm} 3$ (Fig.4). At the same time, there is a constant increase in the share of cars with self-ignition engines from $8 \%$ in 2000 to over $29 \%$ in 2015 and cars with engines adapted to LPG from $7 \%$ to over $14 \%$ respectively (Figure 5). The unfavorable age structure of imported used passenger cars to the country significantly affected the deterioration of the age structure of the passenger car park registered in Poland.

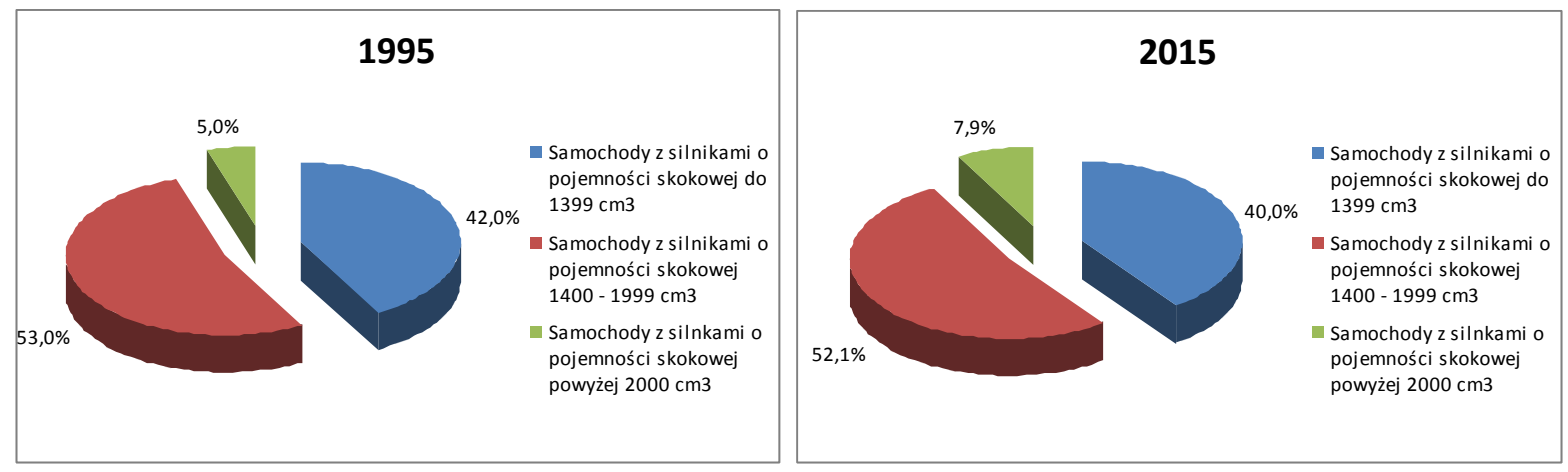

4. Registered passenger cars acc. engine capacity in 1995 - 2015, in\%

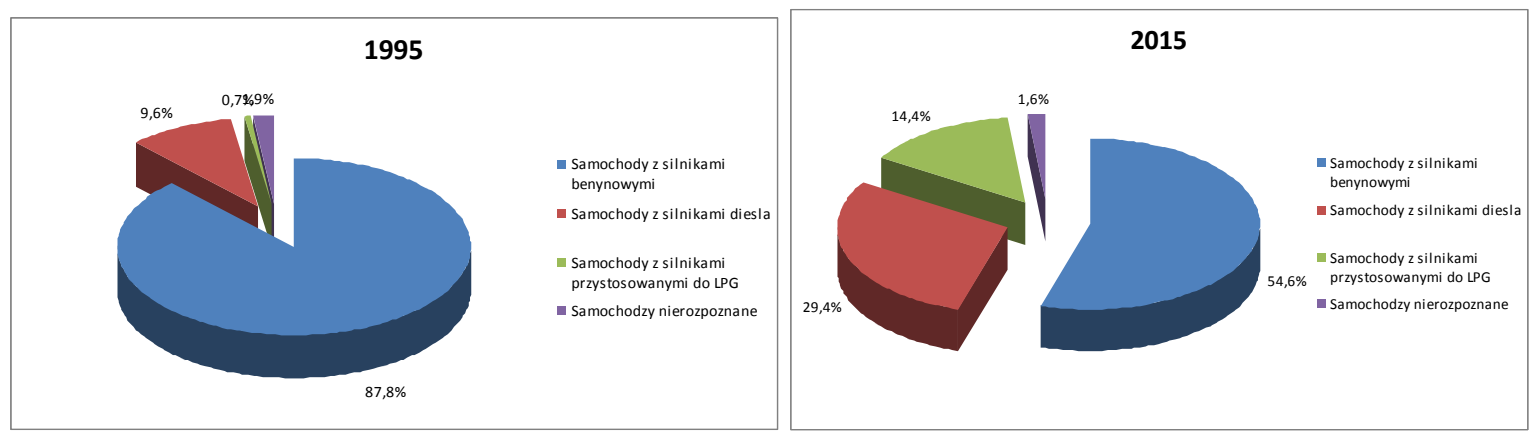

5. Registered passenger cars acc. type of fuel used in $1995-2015$, in $\%$

\section{Poles' mobility in 1990-2015}

Mobility understood as transport performance realized with the help of passenger cars (the product of the number of vehicles operated by the park of registered passenger cars and the number of people transported by a statistical vehicle) remains in Poland subject to only rough estimates. This results both from the lack of systematic surveys of average annual mileage of various categories of motor vehicles (only from January 1, 2014 assessing the mandatory technical review of the car is required to record the mileage), as well as the fact that carried out in the five-year cycle by Trans project-Warsaw load tests motor vehicles apply only to the so-called national roads, where the gross road traffic is concentrated, but which constitute 
only a few percent of the entire road network. These estimates also complicate the problem of a significant, estimated at $20-25 \%$, the difference between the number of registered passenger cars and the number of vehicles actually used. Data from these studies on the traffic load of motor vehicles of the national road network show that the average daily traffic of such vehicles increased in the years 1990-2015 almost fivefold (from 2,280 to 11,178 vehicles), while the traffic of passenger cars on national roads increased more than 6 times from 1273 up to 8015 cars (tab.7).

Tab. 7. Traffic load of motor vehicles of the national road network in 1990-2015, in vehicles / day

\begin{tabular}{|l|r|r|r|r|r|r|}
\hline Specification & $\mathbf{1 9 9 0}(\mathbf{1})$ & $\mathbf{1 9 9 5}(\mathbf{2})$ & $\mathbf{2 0 0 0}$ & $\mathbf{2 0 0 5}$ & $\mathbf{2 0 1 0}$ & $\mathbf{2 0 1 5}$ \\
\hline Total national roads & 2280 & 5350 & 7009 & 8244 & 9888 & 11178 \\
\hline including passenger cars & 1273 & 3811 & 4931 & 5799 & 6914 & 8015 \\
\hline International roads & $\mathbf{\bullet}$ & 8543 & 11448 & 13561 & 16667 & 20067 \\
\hline Other national roads & $\mathbf{\bullet}$ & 3991 & 5109 & 5990 & 7097 & 7614 \\
\hline
\end{tabular}

1) results from 1990 calculated for the national road network acc. categorization in force in 1990

2) results in 1995 calculated for the national road network by categorization in force since January 1999u

Source: based on own elaboration:

1990 - Traffic 1990 Transprojekt-Warsaw, Warsaw 1992

1995-2000 - General Movement Measurement 2000. Synthesis of results and elaboration K. Opoczyński, TransprojektWarszawa Sp. z o.o., Warsaw 2001, pp. 4 and 10

2005 - General Movement Measurement 2005. Synthesis of results and elaboration K. Opoczyński, Transprojekt-Warszawa Sp. z o.o., Warsaw 2006, pp. 3 and 10

2010 - General Traffic Measurement 2010. Synthesis of results and elaboration K. Opoczyński, Transprojekt-Warszawa Sp. z o.o., Warsaw 2011, pp.4i 12

2015 - General Traffic Measurement 2015 on an off-road national road network. Transprojekt-Warszawa Sp. z o.o., Warsaw 2016, pp. 9 and 15

The average daily traffic of motor vehicles on the national road network in 1990-1995 increased by $136 \%$, in $1995-2000$ by $31 \%$, in $2000-2005$ by $18 \%$, in $2005-2010$ by $22 \%$ and in $2010-2015$ by $14 \%$, including passenger car traffic increased by $199 \%$ in $1990-1995$, by $1995-2000$ by $29 \%$, in $2000-2005$ by $17 \%$, in $2005-2010$ by $22 \%$ and in $2010-2015$ by $17 \%$. The load on national roads by motor vehicles (in the absence of category separation of vehicles) was higher and was growing at a higher pace on international roads, from 8.5 thousand vehicles / day in 1995 to 20,000 vehicles / day in 2015 (2.5 times increase) compared to other national roads (increase from about 4,000 vehicles / day in 1995 to 7.6 thousand vehicles a day in 2015 - increase less than 2 times).

The traffic of passenger cars across the country's territory has been estimated by the Central Statistical Office since 2005 (tab.8).

The estimates show that the road traffic of passenger cars on the territory of Poland increased from around 55 billion VKT in 1990 to 182 billion VKT in 2014 (an increase of over three times). On the most-loaded sections of national roads according to recent surveys from 2015, the average daily traffic of cars exceeded 100,000. vehicles (eg 142 thousand vehicles within the Warsaw Trasa Toruńska, 112 thousand vehicles on the S-86 road between Sosnowiec and Katowice, 101 thousand vehicles on A4 in Katowice).

The share of passenger car traffic oscillates constantly within $80 \%$ of all road traffic of motor vehicles. In 2005-2013, according to GUS estimates, approximately 1/3 of the domestic passenger car traffic was in urban (built-up) areas, and two-thirds traffic outside urban (urban) areas. Despite more than twofold growth of passenger traffic on motorways (from 2.1 to 5.0 billion), the share of motorway traffic in total road passenger cars increased from $1.6 \%$ to just under 3\%. When comparing data on the total mileage of passenger cars in 2005-2013 with the numbers registered in the country in individual years of passenger cars, the average annual 
mileage of a registered passenger car is obtained on the level: from 10.4 thousand $\mathrm{km}$ in 2005 , by 9.2 thousand $\mathrm{km}$ in 2010, up to 9.1 thousand $\mathrm{km}$ in 2014 [7].

The progressive decrease of the average annual statistical mileage of a passenger car results from the numerical development of individual motorization, on the one hand gradually encompassing less and less mobile members of society with more modest possibilities of car ownership costs, on the other hand from the growth of the second and more cars in households and the distribution of their needs transport for several vehicles.

Tab. 8. Traffic of passenger cars on the territory of the country in the years $2005-2014$ by the category of roads, in billion of VKT.

\begin{tabular}{|c|c|c|c|c|c|c|}
\hline \multirow[t]{2}{*}{ Specification } & \multicolumn{2}{|c|}{ Altogether } & \multirow[t]{2}{*}{ Highways } & \multicolumn{3}{|c|}{ Other roads } \\
\hline & Total & $\begin{array}{l}\text { including } \\
\text { the TEN- } \\
\mathrm{T} \\
\text { network }\end{array}$ & & Total & In built-up area & $\begin{array}{l}\text { Outside the built- } \\
\text { up area }\end{array}$ \\
\hline 2005 & 127,9 & 9,7 & 2,1 & 125,9 & 41,0 & 84,9 \\
\hline 2008 & 144,9 & 10,7 & 2,9 & 142,0 & 45,2 & 96,8 \\
\hline 2009 & 153,5 & 11,5 & 3,8 & 149,6 & 48,5 & 101,1 \\
\hline 2010 & 159,3 & 17,7 & 4,5 & 154,8 & 50,3 & 104,5 \\
\hline 2011 & 165,6 & 18,4 & 4,5 & 161,0 & 52,6 & 108,4 \\
\hline 2012 & 166,1 & 19,0 & 4,8 & 151,3 & 52,5 & 108,8 \\
\hline 2013 & 169,7 & 19,8 & 5,0 & 164,7 & 53,7 & 111,0 \\
\hline 2014 & 182,6 & $\bullet$ & $\bullet$ & $\bullet$ & $\bullet$ & $\bullet$ \\
\hline \multicolumn{7}{|c|}{ Source: own work based on: } \\
\hline $2005-2009$ & $\begin{array}{l}\text { Road } \\
\text { Tabl.2 }\end{array}$ & $\begin{array}{l}\text { ansport in } \\
19 \text { p. } 109\end{array}$ & oland in the year & $2005-200$ & , GUS Szczecin 2011 & Tabl.28 p.108, \\
\hline $2010-2011$ & $\begin{array}{l}\text { Road } \\
\text { Tabl.2 }\end{array}$ & $20 \mathrm{~s} .124$ & oland in the year: & $2010-201$ & , Central Statistical O & fice, Szczecin, 2013, \\
\hline $2012-2013$ & Road & ransport in 1 & oland in the year: & $2012-201$ & GUS, Szczecin 2015 & table.20 p.125 \\
\hline
\end{tabular}

The results of the research already published in the Przegląd Komunikacyjny, and conducted in 2013-2014 by the Motor Transport Institute, also confirm the occurrence of trends known in developed Western European countries regarding the average mileage of passenger cars in Poland. Cars with self-ignition engines and LPG-powered engines, in each age group, as well as in each group of displacement volumes perform much higher annual runs than their petrol-powered counterparts. The average mileages of the passenger cars under test also increase significantly with the increase of engine capacity and decrease with the growing age of the vehicles tested [10] .

Comparing data on the number of passenger cars registered in Poland in 1990, 1995, 2000 with an average annual mileage of a statistical car in 2005 of 10.5 thousand $\mathrm{km}$, their total annual mileage can be estimated in years not covered by GUS estimates for: 55.2 bn VKT in 1990, 78.9 bn VKT in 1995 and 104.9 bn VKT in 2000, which coincides with or minus the estimates of other authors [15].

Relatively the greatest dose of uncertainty is burdened with data on passenger transport carried out in individual years using passenger cars, expressed in passengerkilometers. According to the last available EU source, in 2015 the number of passenger kilometers measured by passenger cars in Poland was: 110 billion in 1995, 130 billion in 2000, 152 billion in 2005, 190 billion in 2010, 213 billion in 2013 and 218.9 billion in 2014 [4].

Meanwhile, in the corresponding 2011 source, the corresponding figures were: 2000 150 billion passenger-kilometers, 2005-197 billion passenger-kilometers, and, for example, 285 billion passenger-kilometers for 2009 (nearly 100 billion passenger-kilometers more than in the quoted source from 2016) [3]. 
In the absence of a basis for a critical analysis of these differences (most likely resulting from the adoption of different values of the average passenger car filling index), the data from the 2016 source calculated based on the average occupancy rate in 2005-2013 at the level of 1.2-1.25 people / vehicle and with a 1.4 persons / vehicle ratio in the years 19902000. The reduction in the value of average passenger car filling indicator results from analogous reasons as in the case of a decrease in the average annual statistical mileage of the car, i.e. an increase in the saturation of the society with cars, including the development of the second and more cars in an increasing number of households.

Under the adopted assumptions, passenger car transport in 1990 - 2014 increased almost threefold, with 77 billion passenger-km in 1990 to 219 billion passenger-km in 2014 (tab.9).

Tab. 9. Runs and transport work carried out with passenger cars in Poland in the years 1990 2014.

\begin{tabular}{|c|c|c|c|c|}
\hline Year & $\begin{array}{l}\text { Mileagess in a } \\
\text { billion VKT }\end{array}$ & $\begin{array}{l}\text { Average occupancy } \\
\text { rate in people / vehicle }\end{array}$ & $\begin{array}{l}\text { Passenger transport } \\
\text { carried out in billions }\end{array}$ & $\begin{array}{l}\text { Share of passenger } \\
\text { cars in passenger } \\
\text { transport work, in } \%\end{array}$ \\
\hline 1990 & 55,2 & 1,40 & 77,0 & 37 \\
\hline 1995 & 78,9 & 1,40 & 110,2 & 45 \\
\hline 2000 & 104,9 & 1,40 & 130,1 & 57 \\
\hline 2005 & 127,9 & 1,19 & 152,3 & 65 \\
\hline 2010 & 159,3 & 1,19 & 188,8 & 72 \\
\hline 2013 & 169,7 & 1,25 & 213,3 & 74 \\
\hline 2014 & 182,6 & 1,20 & 218,9 & 75 \\
\hline
\end{tabular}

Source: Own elaboration based on road traffic data in the years 2005-2014 from CSO studies and based on data on transport performance with EU - Transport in Figures, Statistical Pocketbook 2016.

It is difficult to make a one-dimensional assessment of the causes of an almost threefold increase in the mobility of Poles in 1990 - 2014. "It is not clear whether this increase in the number of passenger cars results in increased mobility or increased mobility (caused by other factors, including spatial nature), which results in the acceleration of motorisation in conditions of low supply of public transport" [6]."Well-developed public transport reduces the level of motorization by about $12 \%$, affecting primarily the possession of second and third vehicles in the household" [6].

The increase in passenger car transport with a simultaneous decrease in transport performed both by urban (bus and rail) transport and extra-urban (rail and bus) transport has fundamentally changed the branch structure of Polish passenger transport. In 1990, the share of individual motoring in the transport of Polish passenger transport was $37 \%$, to exceed $75 \%$ in 2014.

\section{Summary}

- The quarter-century 1990-2015 was characterized by a unique, even on a global scale, dynamics of the development of individual motorisation (the number of registered passenger cars increased almost four times (from 5.2 million to 20.7 million), the number of completed passenger cars mileage more than tripled (from 55 billion up to 182 billion VKT), and passenger carriages fewer than three times (from 77 billion to 218.9 billion passenger kilometers). The slower growth of road traffic than the number of vehicles results from the fact that, on the one hand, vehicle owners are also less mobile members of society with more modest possibilities of incurring the costs of operating vehicles, and on the other hand with increasing the phenomenon of the second and more car in households and the distribution of their transport needs for several vehicles. 
- The four-fold increase in the park of registered passenger cars in Poland was accompanied by a radical change in its brand-age structure, while in 1990-2000 this increase was primarily generated by the sale of new cars, including those from factories located in Poland, in subsequent years, particularly since 2004, this growth has generated import of used cars (imported to Poland in 1990-2015: over 11 million used passenger cars, including 2004-2015: 9.6 million vehicles), which began to affect the permanent deterioration of the age structure of the national park passenger cars. Today, more than $70 \%$ of registered passenger cars in Poland are 10 and more years old.

- The growth of the passenger car park was accompanied by a change in its fuelcapacitive structure: the share of cars with gasoline engines dropped from $85 \%$ in 2000 to $54.6 \%$ in 2015 , with the simultaneous increase in the share of cars with selfignition engines and cars with engines adapted to LPG respectively from 8 and $7 \%$ to $29.4 \%$ and $14.4 \%$. The share of cars with engines up to $1399 \mathrm{~cm}^{3}$ and medium capacity up to $1999 \mathrm{cc}$ decreased from 42 and 53 per cent in 1995 to respectively 40 and 50 per cent in 2015, with a 3-point increase in cars with engines with capacities above $2000 \mathrm{~cm}^{3}$.

- The development of the park and passenger car traffic (constituting $80 \%$ of all road traffic) took place, especially in the fifteen-year period 1990-2004, in the absence of a significant improvement in both lengths and, above all, the quality of the road network. Positive changes in this respect were brought only in the years 2000-2015, in which the over $1,400 \mathrm{~km}$ of expressways and over $1,300 \mathrm{~km}$ of motorways and several dozens bypasses around urban centers of various sizes.

- Fragmentation and imperfections of state statistics, in the absence of in-depth appropriate systemic research, makes it difficult to precisely assess the actual level of development of individual motoring and its place in the country's transport system.

- It does not change the fact that regardless of the estimated nature of the presented data, the development of individual motorisation recorded in the quarter of a century has fundamentally changed the transport landscape of Poland.

- The increase in the share of individual motoring in the balance of Polish passenger transport balance from $37 \%$ in 1990 to $75 \%$ in 2014 made this transport similar to passenger transport in developed countries of Western Europe.

\section{Source materials}

[1] Annales Statistiques de Transport 1965-1987, ECMT, Luksemburg 1990

[2] Balke I., Balke M.: Badanie struktury krajowego parku wybranych rodzajów pojazdów w 2014 i 2015 roku. Stan rejestracji oraz oszacowanie liczby pojazdów eksploatowanych, Praca ITS/6501/ZBE, Warszawa 2016

[3] EU transport in figures, Statistical Pocketbook 2011, European Commission 2011

[4] EU transport in figures, Statistical Pocketbook 2016, European Commission 2016

[5] Klimkowski R.: Przemysł samochodów osobowych w Polsce i jego uwarunkowania w latach transformacji systemowej 1990-2014, Nierówności społeczne a wzrost gospodarczy, $\mathrm{nr}$ 3/2005

[6] Komornicki, Przemiany mobilności codziennej Polaków na tle rozwoju motoryzacji, IGiPZ PAN, 2011

[7] Krysiuk C., Zakrzewski B., Waśkiewicz J.: Pojazdy w transporcie drogowym w Polsce w 2005 roku oraz ich średnie roczne przebiegi w aspekcie zanieczyszczeń z silników spalinowych, część II - Szacunki 
średnich przebiegów parku samochodowego wg wyspecyfikowanych kategorii, temat nr 6607/ZBE, Warszawa, czerwiec 2006

[8] Kublik A.: Nowe auta staniały bo wjechały stare, Gazeta Wyborcza z 8 maja 2014 roku

[9] Menes E.: Dylematy rozwoju indywidualnej motoryzacji w Polsce. Zeszyt Naukowy ITS nr 87, Warszawa 1998

[10] Menes M.: Wyniki badań średniorocznych przebiegów samochodów osobowych w Polsce w roku 2014, Przegląd Komunikacyjny nr 5/2015

[11]Piskozub A.: Zarys najnowszych dziejów transportu , Warszawa, WKiŁ 1979

[12] Raport Polskiego Związku Producentów Motoryzacyjnych, Warszawa 2016

[13] Roczniki Statystyczne Handlu Zagranicznego; 2010, 2013, 2014, GUS Warszawa: 2010, 2013, 2014

[14] Waśkiewicz J.: Badanie i analiza zmian w wielkości i strukturze parku samochodowego w Polsce, tom IV Zmiany struktury markowej i liczebności parku samochodowego w Polsce, praca ITS nr 2421/ZBN, Warszawa 2004

[15] Waśkiewicz J.: Ograniczenie energochłonności transportu samochodowego w Polsce (projekt badawczy KBN nr 79 / 12 C 0800012; praca ITS nr 9080 / ZBN, Warszawa 1998 